Ilmenau University of Technology

Institute of Economics

Ilmenau Economics Discussion Papers, Vol. 25, No. 130

\title{
Public Interest Considerations in European Merger Control Regimes
}

Oliver Budzinski \& Annika Stöhr

August 2019

Institute of Economics

Ehrenbergstraße 29

Ernst-Abbe-Zentrum

D-98 684 Ilmenau

Phone 03677/69-4030/-4032

Fax 03677/69-4203

https://www.tu-ilmenau.de/wm/fakultaet/

ISSN 0949-3859 


\title{
Public Interest Considerations in European Merger Control Regimes
}

\author{
Oliver Budzinski" \& Annika Stöhr ${ }^{*}$
}

\begin{abstract}
Nowadays, merger control predominantly relies upon a strict analysis of the effects from merger and acquisitions on effective competition. However, there is scope for so-called public interest considerations in several European merger control regimes and recently a number of European politicians have called for more elbowroom for non-competition-oriented interventions into merger control. For instance, they did so in the context of the prohibition of the Siemens-Alstommerger and the upcoming industrial policy discussion about European Champions.
\end{abstract} Since the social welfare effects of competitive markets present an important public interest in itself, additional public interest considerations justifying an intervention need to be non-market in the sense that these goals stand in conflict with competition. However, a trade-off between effective competition and public interest, i.e. public interests that are better served through market power then through effective competition, is a rare phenomenon. This paper gives an overview of public interest considerations in the merger policy of European Union member states and analyzes four jurisdictions in more detail. We find that the institutional designs how public interests considerations are included in the merger control regimes lack focus on non-market public interest considerations across the analyzed jurisdictions. Furthermore, there are relevant shortcomings regarding transparency and legal certainty. Moreover, our ex-pots analysis shows that the empirical record of past public interest-motivated interventions is questionable with only few interventions yielding the desired effects. Therefore, we suggest revising the public interest regulations in the respective merger control regulations by narrowing their focus to real

\# Professor of Economic Theory, Institute of Economics, Institute of Media and Mobile Communication, Ilmenau University of Technology, Germany, Email: oliver.budzinski@tu-ilmenau.de.

M.Sc., Institute of Economics, Ilmenau University of Technology, Germany, Email: annika.stoehr@tu-ilmenau.de.

+ We like to thank the participants of the $14^{\text {th }}$ ASCOLA Conference "Challenges to the Assumptions at the Basis of Competition Law" (Aix-en-Provence, June 2019) and the 2019 Annual Conference of the German Law \& Economics Association (Hanover, July 2019) for valuable comments on an earlier version of the paper. 
non-market public interests and by levying decision power on less politicallyinfluenced bodies.

Keywords: competition policy, antitrust, merger control, industrial economics, public interest, governance, competition law, law \& economics, institutional economics, German competition policy, UK competition policy, French competition policy, Austrian competition policy

JEL-Codes: K21, K23, D43, L51, F52, F55 


\section{Contents}

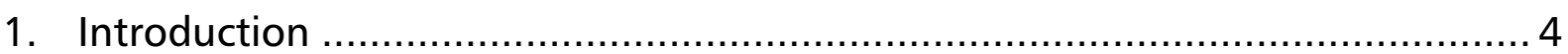

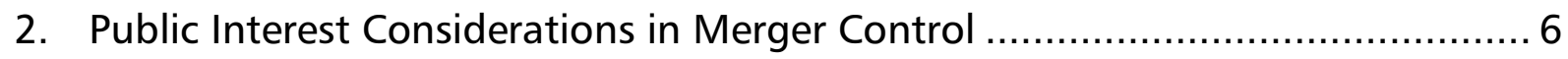

2.1 Public Interest Considerations in Austrian Merger Control ..................... 10

2.2 Public Interest Considerations in French Merger Control........................ 14

2.3 Public Interest Considerations in UK Merger Control.......................... 17

3. The Special Case of "Ministererlaubnis" in German Merger Control ............... 20

4. Concluding Remarks: Economic Justification of Public Interest Considerations in

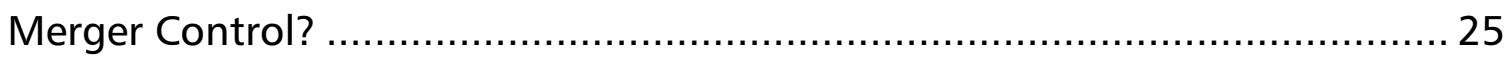

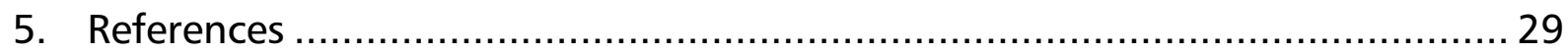




\section{Introduction}

Protecting and safeguarding market competition as the principal coordination mechanism of supply and demand serves the public interest. Coordinating economic activities through competitive markets provides a superior solution to the fundamental problem of scarcity than any other mechanisms known so far. ${ }^{1}$ Consequently, market competition generates more social welfare than any alternative coordination mechanism. Notwithstanding, there may be additional public interests that may stand in conflict with market competition. Some of them may require additional policy tools adjusting market results according to these goals, like for instance in the case of income redistribution through taxes and social services. In these cases, having effectively competitive markets as a starting point is still beneficial for public interest. In rare cases, however, a social goal may be better achieved through the natural opposite of competition, i.e. through market power, than through competition. We will call such goals non-market public interest. If there is a trade-off between effective competition and public interest (i.e. public interests that are better served through market power then through effective competition), then a democratic society must be allowed to value the conflicting goal higher than the welfare effects of effective competition (in this special area), given the decision process is made under awareness of the welfare costs of pursuing the conflicting public interest. Therefore, it cannot be denied that there may be scope for correcting purely competition-based decisions on non-market public interest grounds. Note, however, that in the real world, vested interests may hide behind ostensible

\footnotetext{
The theories of market failure do stand in contrast to this general wisdom. The term market "failure", for instance through serious externalities or massive and strategically-exploitable asymmetric information, is somewhat misleading since it "only" implies that markets do not achieve the perfect level of social welfare all alone. Intelligent institutions (as rules of the game) and smart interventions may improve social welfare in these cases. Notwithstanding, the market does not "fail"; it still produces superior results to alternative coordination mechanisms. Note also that only ingeniously-designed interventions may improve welfare here; real-world interventions, distorted by imperfect political and administrative processes and influenced by lobbyism, may actually perform worse than the imperfect market. Thus, the theories of market failure are rather theories of market imperfections and do not represent cases where less competition serves the public interest better than more competition. This is even true for the extreme case of positive externalities called public goods in economics. The rare cases where users of a non-rival good cannot be excluded from consumption because of inherent goods characteristics imply the necessity for the public to enforce payment of users in order to avoid widespread free rider problems - but notwithstanding a competitive market still serves welfare better than a monopoly or bureaucratic administration.
} 
public interests in order to protect and/or create non-competitive rents - at the expense of society. In an imperfect world, the identification problem of real public interest versus ostensible public interest is likely to be considerable given the imperfections of political and administrative processes and the power of lobbyism.

Merger control represents a particular relevant field of competition policy where these types of public interest considerations play a role. Competition authorities analyse mergers and acquisitions with respect to their effects on competition. The goal of merger control is to protect competition through blocking combinations of companies that substantially or significantly lessen competition in the affected markets. However, in exceptional cases, non-market public interest considerations may justify to allow for anticompetitive concentration if two conditions are fulfilled: (i) the non-market public interests outweigh the public interest of having competitive markets and (ii) the anticompetitive merger is instrumental for achieving the respective non-market public interest goal. While the public interest-based clearance of an anticompetitive concentration (i.e. a merger or an acquisition that was blocked by the antitrust authority because it lessens/impedes competition) is the dominant case, it is also conceivable that a procompetitive merger gets challenged on non-market public interest grounds. Here, antitrust authorities would allow the merger because of a lack of significant anticompetitive effects and/or considerable efficiency advantages, whereas non-market public interest considerations advocate blocking the merger. ${ }^{2}$

The topic of public interest considerations in merger control recently received renewed attention in the context of the European's Commission decision to block the merger between Siemens and Alstom (European Commission 2019). Politicians from the home countries of the two companies cried out and eventually a "FrancoGerman Manifesto for a European industrial policy fit for the $21^{\text {st }}$ Century" was published (BMWi 2019). Here the German and French Ministers for Economic Affairs, among different regulatory and other changes, suggest an appellation right for the European Council, so that it can override merger prohibitions by the Euro-

2 Note that this type of overruling competition-effects-based merger control decisions has nothing to do with enforcement problems of merger control authorities against anticompetitive mergers (inter alia, Budzinski 2010) or with legal appeal or revision (inter alia, Pappas \& Demortain 2004; Barbier de la Serre 2006). 
pean Commission on the grounds of public interest considerations. This proposal would extend an already long list of public interest considerations and exceptions in European merger control regimes like, for instance, in the British Merger Assessment Guidelines, the German Law against Restraints of Competition (Gesetz gegen Wettbewerbsbeschränkungen; GWB), and the French Code de Commerce. Public interest aspects in merger control regimes include securing jobs, supplying goods such as energy and medical care, or preserving the free press. Obviously, however, some of these public interest considerations clearly do not match our definition of non-market public, as they do not trade-off with effective competition.

This contribution aims to give an overview on public interest considerations in European merger control regimes by taking a deeper look into German merger control, where the Federal Minister of Economic Affairs may allow a merger deemed to be anticompetitive by the Federal Cartel Office (FCO) on public interest grounds (so-called ministerial approval; "Ministererlaubnis"). We answer the research questions (i) whether the public interests stipulated in the respective competition laws are non-market in nature, and (ii) if, in anecdotally chosen cases, the respective permitted anticompetitive mergers were instrumental to achieve the stated nonmarket public interest goals. For the German case study, we (iii) provide an overview whether the postulated public interest goals have ex-post been promoted by the past case of ministerial exemptions. We conclude that the ways public interests are currently included in merger control regime in Europe are deficient, in particular because they are not restricted to non-market public interests and the institutional design offers ample scope for political and lobbyistic influence, pretending to follow public interest when actually vested interests are pursued.

\section{Public Interest Considerations in Merger Control}

In the European Union, merger control takes place on the European level (based upon EU law with the European Commission as the competition authority) as well as on the member state level (based upon national law enforced by national com- 
petition laws). Additionally, member states can also directly apply European law. ${ }^{3}$ Under strict conditions, member states have the possibility to consider public interests when applying EU law by the provisions of Article 21 EUMR. Public security, plurality of the media and prudential rules are seen as prima facie legitimate to constitute exceptions for the otherwise exclusive consideration of competitive aspects, whereas the European Commission (EC) may decide case-by-case if other public interest aspects can ex-ante be applied in a given merger case (OECD 2016b: 6).

The different member states of the EU design their merger control regimes individually and can therefore decide whether they include public interest considerations or not. If they do, they can shape their regulations differently, e.g. in terms of sectors covered, consequences of a successful application of public interest considerations in a merger case, or the decisive body that is allowed to clear or prohibit a merger based on public interests. Table 1 gives an overview of the $28 \mathrm{EU}$ member states and the different ways of including public interest considerations into their merger control. Shown are all states in which the respective public interest aspects are actually included in competition law - besides that, there are several states that include public interest considerations on single case level, which have no explicit legal basis. That makes a deeper investigation of the instruments and the reasons behind the usage difficult and, in tendency, inaccurate. Thus, they are not included in table 1 and will not be analysed in this paper.

Table 1: Public Interest Considerations in EU Merger Control Regimes

\begin{tabular}{|c|c|}
\hline Country & Public Interest Considerations in Merger Control \\
\hline Austria & $\begin{array}{l}\text { - Applied in merger cases in the media industry, here the merger } \\
\text { is to be blocked if it is likely to decrease media plurality ( } \$ 13 \\
\text { KartG) } \\
\text { - So-called "Federal Cartel Prosecutor" to represent public inter- } \\
\text { ests in important cases or industries ( } \$ 75 \text { KartG) }\end{array}$ \\
\hline Belgium & - None \\
\hline Bulgaria & - None \\
\hline Croatia & - None \\
\hline
\end{tabular}

See for questions of competence allocation and delineation Budzinski \& Christiansen (2005) and Budzinski (2006, 2018). 


\begin{tabular}{|c|c|c|}
\hline Republic of Cyprus & - & None \\
\hline Czech Republic & - & None \\
\hline Denmark & - & None \\
\hline Estonia & - & None \\
\hline Finland & & $\begin{array}{l}\text { Electricity market has special thresholds: total volume of electric- } \\
\text { ity distributed at } 400 \mathrm{~V} \text { or number of electricity plants belonging } \\
\text { to the merging parties amounts to over } 25 \% \text { of the national } \\
\text { electricity grid post-merger - intervention in mergers does not } \\
\text { require that a significant impediment to effective competition } \\
\text { can be demonstrated (Section } 25 \text { of the Finnish Competition } \\
\text { Act) }\end{array}$ \\
\hline France & - & $\begin{array}{l}\text { Minister for Economic Affairs has power to evoke a case for rea- } \\
\text { sons of general interest other than maintaining competition, in } \\
\text { particular industrial development, competitiveness of undertak- } \\
\text { ings relative to international competition, or crea- } \\
\text { tion/maintenance of jobs (Article L. } 430 \text { - } 7 \text { - } 1 \text { Code de Com- } \\
\text { merce) }\end{array}$ \\
\hline Germany & - & $\begin{array}{l}\text { Minister of Economic Affairs can clear a blocked merger based } \\
\text { on specified public interest considerations (competitiveness of } \\
\text { undertakings relative to international competition, macroeco- } \\
\text { nomic advantages, or outstanding interest of the general public) } \\
\text { after the Bundeskartellamt has blocked it solely based on com- } \\
\text { petition aspects ( } \$ 42 \mathrm{GWB} \text { ) }\end{array}$ \\
\hline Greece & - & None \\
\hline Hungary & & $\begin{array}{l}\text { Merger that helps to preserve jobs or to assure security of supply } \\
\text { can be claimed to be of strategic importance at the national lev- } \\
\text { el (Article 24/A of the Competition Act) }\end{array}$ \\
\hline Ireland & - & $\begin{array}{l}\text { Special rules for mergers in the media sector (section } 23 \text { of the } \\
\text { Competition Act) }\end{array}$ \\
\hline Italy & & $\begin{array}{l}\text { Italian Competition Authority (ICA) can exceptionally allow an } \\
\text { otherwise prohibited merger if relevant national economic inter- } \\
\text { ests are involved (Article } 25 \text { (1) of Law No. 287/90) } \\
\text { After clearance by the ICA, Italian Prime Minister can prohibit the } \\
\text { acquisition of an Italian company by a foreign firm if in the for- } \\
\text { eign country Italian undertakings are discriminated, especially in } \\
\text { connection with the ability of Italian firms to acquire local com- } \\
\text { panies (Article } 25 \text { (2) of Law No. 287/90) } \\
\text { ICA can clear an anticompetitive merger in the banking sector to } \\
\text { protect the economic stability of one or more parties involved in } \\
\text { the merger (Article } 25 \text { (5-bis) of Law No. 287/90) } \\
\text { When reviewing mergers involving insurance companies, ICA } \\
\text { has to consult the responsible sector regulator IVASS before } \\
\text { making a decision (Article } 25 \text { of Law No. 287/90) }\end{array}$ \\
\hline Latvia & - & None \\
\hline Lithuania & - & None \\
\hline Luxembourg & - & None \\
\hline Malta & - & None \\
\hline Netherlands & - & Minister of Economic Affairs can clear a blocked merger based \\
\hline
\end{tabular}




\begin{tabular}{|c|c|c|}
\hline & & $\begin{array}{l}\text { on not specified public interest considerations (Article } 47 \text { of the } \\
\text { Dutch Competition Act) }\end{array}$ \\
\hline Poland & - & None \\
\hline Portugal & - & $\begin{array}{l}\text { Regulatory Authority for the Media can intervene to protect } \\
\text { freedom and pluralism of the media (Article 4B of the Portu- } \\
\text { guese Television Act) } \\
\text { Government (Council of Ministers) can intervene based on fun- } \\
\text { damental strategic interests of the national economy (Article } 41 \\
\text { of the } 2014 \text { PCA's By-laws) }\end{array}$ \\
\hline Romania & - & None \\
\hline Slovakia & - & None \\
\hline Slovenia & - & None \\
\hline Spain & - & $\begin{array}{l}\text { Council of Ministers can clear a prohibited merger regarding } \\
\text { public interests other than protecting competition (Article } 10 \text { of } \\
\text { the Competition Act 15/2007): } \\
\circ \text { defence and national security, } \\
\circ \text { protection of public security or public health, } \\
\circ \text { free movement of goods and services within the national } \\
\text { territory, } \\
\circ \text { environment protection, } \\
\circ \text { promotion of technological research and development, } \\
\circ \text { guarantee of adequate maintenance of the objectives of } \\
\text { sectorial regulation }\end{array}$ \\
\hline Sweden & - & None \\
\hline United Kingdom & - & $\begin{array}{l}\text { Secretary of State can issue an intervention notice to the Mo- } \\
\text { nopolies and Merger Commission (MMC) if he considers one or } \\
\text { more of the following public interest aspects to be present in a } \\
\text { particular merger review process: national security, media plural- } \\
\text { ity, stability of the UK financial system (section } 58 \text { of the Enter- } \\
\text { prise Act); these specified considerations apply to three types of } \\
\text { mergers: public interest mergers, special public interest mergers, } \\
\text { European relevant merger situations (Enterprise Act 2002) }\end{array}$ \\
\hline
\end{tabular}

For a deeper analysis, we choose four European countries where public interest considerations are included in the respective competition law. We describe public interest aspects in the Austrian, German, French and UK Merger control. To ensure comparability of our analysis, we examine the different merger control regimes under the same comparative values: (i) we first check if the respective regime stipulates truly non-market public interests following our definition in the introduction. Secondly (ii), we analyse the instruments with regard to their transparency and the legal certainty for all parties involved. In a third and fourth step, we (iii) look into the frequency of the actual usage of the instruments and (iv) evaluate anecdotally if the decisions to allow anticompetitive concentration actually promoted public in- 
terest. In this step, we analyse if the anticompetitive merger was instrumental to reach the respective non-market public interest goals. The last step (v) is a final evaluation of the respective instrument in terms of asking if it is, in its current form, suitable to include important non-market aspects into merger control decisions.

\subsection{Public Interest Considerations in Austrian Merger Control}

In Austrian merger legislation, public interests have to be taken into account regarding media mergers. Besides anticompetitive effects, media mergers can also have negative effects in terms of decreasing media plurality and increasing media bias. If a merger between media companies is likely to decrease media plurality, it is to be prohibited ( $\$ 13$ KartG). Media plurality is defined by the Austrian competition law as "a variety of independent media companies, which are not related to each other within the meaning of $\S 7 \mathrm{KartG}$ and by which a media coverage of different opinions is ensured" ( $\$ 13$ (2) KartG). Hence, media plurality is not only about a wide variety of titles; instead, independent coverage has to be ensured through a respective ownership structure (Bundeskanzleramt 2019). Higher concentration in this market, therefore, can be seen as a threat to media plurality - which shows that protection of competition and public interest considerations are not mutually exclusive here, but act in the same direction.

Besides the application of public interests in media mergers there is another particularity in Austrian merger control: the so-called "Bundeskartellanwalt" (Federal Cartel Prosecutor, FCP), whose role was implemented in Austrian merger control in 2002 (Beirat für Wirtschafts- und Sozialfragen 2010). His main task is "the representation of public interests in matters of competition law at the Higher Regional Court of Vienna as a cartel court" ( $\$ 75 \mathrm{KartG})$. What constitutes public interests in the context of this law, however, is not defined in detail. The FCP can file an application for the opening of a case. Furthermore, he can be a party to antitrust proceedings in which he is not an applicant (Bundesministerium Verfassung, Reformen, Deregulierung und Justiz 2019).

An evaluation of the two particularities of the Austrian merger control regime regarding our five criteria yields the following insights: 
(i) Non-Market Public Interests:

The analysis of the Austrian merger control needs to be divided into its two different parts: the special regulation of media mergers and the institution FCP. Media plurality, minimization of media bias, and independent media coverage could be seen as non-market public interest reasons for otherwise anticompetitive mergers if market-powerful media companies experience less incentives to bias news than media firms facing intensive competition (Mullainathan \& Shleifer 2005). However, under empirically realistic conditions like imperfect information, information asymmetries, and the presence of politically-motivated media entrepreneurs, effective competition among media companies serves the goals of media plurality, minimization of media bias, and independent news coverage better than narrow oligopolies or a powerful monopoly (Coase 1974; Gentzkow \& Shapiro 2006, 2008; Anderson \& McLaren 2012). Consequently, these goals can be better achieved through competition than through concentration. Furthermore, the definition of media plurality used by the Austrian competition authorities makes media plurality dependent on the ownership structure and, thus, to a large extent on the competitive conditions on the market. For these reasons, media plurality cannot be seen as a non-market public interest and market power does not contribute to it - but, in contrast, jeopardizes these goals under realistic conditions. ${ }^{4}$

The FCP as further instance able to include public interests into merger proceedings, can also intervene in merger cases on grounds of purely competition-related aspects, for instance, market delineation (inter alia, Mair \& Stifter 2015, 2016; Mair et al. 2017). The public interests the prosecutor has to represent according to the law are not defined in detail but seem to mostly not coincide with our definition of truly non-market aspects that cannot be reached (better) through competition.

There may be a case for a stricter competition policy towards media markets than towards other markets. However, this would be part of the competition rules and their regular enforcement. 
(ii) Transparency:

The regulation of media mergers included in Austrian competition law and the proceedings in such cases seem to be relatively transparent, whereas the tasks of the FCP are less clear and considerably open for interpretation by the respective individual prosecutor. This may be due to the fact that the "public interests" he shall represent in front of the Higher Regional Court of Vienna are not defined by law and, thus, may be interpreted in a broad way. Historically, the FCP was set up to give politicians the opportunity to intervene in antitrust proceedings. In this way the institution FCP potentially strengthens the transparency of antitrust proceedings and the independence of the Austrian competition agency (Beirat für Wirtschafts- und Sozialfragen 2010). Nevertheless, due to the considerable scope for interpretation of public interest, it depends on the individual acting as the FCP whether it weakens or even strengthens the protection of competition.

According to his activity reports of the last years, the current FCP, Alfred Mair, seems to interpret his tasks mostly as the protection of consumer welfare - which can clearly be seen as a public interest in general, but, at the same time, is also the goal of competition policy itself (i.e. achieving social welfare through consumer welfare). As such, it represents no additional and no non-market public interest. The activity reports show a variety of interferences of the FCP in several merger cases - in the media sector and others. However, we did not find any case, where the FCP intervened because of truly non-market aspects; he expressed himself in several proceedings as a representative of the public interest by means of corresponding statements (Mair \& Stifter 2015, 2016; Mair et al. 2017). How exactly that was done and the specific public interest reasons of his interventions are not described in the activity reports. Altogether, the institution FCP lacks transparency, not just in terms of the reasons to intervene, but also in terms of actual tasks both due to the lack of more specific definitions included in competition law or guidelines and the considerable scope of interpretation by the respective prosecutor. That the interpretation of public interest interventions into competition policy proceedings appear to depend on the individual acting as the 
FCP symbolizes significant intransparency and legal uncertainty across appointment periods. While the incumbent officeholder acts in a procompetitive and modest way, things may look very different when another individual takes this office.

(iii) Usage:

As the activity reports show, the FCP intervenes in several cases per year mostly with the aim of improving the respective market delineation and, therefore, preventing or containing anticompetitive effects of mergers. In 2017, he was also active in one merger in the TV sector, where he interfered to implement comprehensive behavioural remedies to especially ensure the diversity of news reporting (Mair \& Stifter 2015, 2016; Mair et al. 2017). Besides this combination of the two public interest consideration possibilities in one case, real non-market public interest cases are rare.

(iv) Success/Instrumentality:

There are positive effects achieved through the FCP - mostly regarding the protection of competition. Due to the rare intervention on non-market public interest grounds, potential effects in this regard are difficult to analyse and assess. Nevertheless, the separate rules for media mergers seem to cause the desired positive effects on overall welfare in terms of the public interest in media plurality. After the 2017 Pro7 Sat1 Puls 4/ATV merger, comprehensive news media coverage could be preserved through behavioural remedies (Mair et al. 2017). Nevertheless, since it required post-merger remedies to safeguard a media plurality that existed pre-merger, it is difficult to understand why a prohibition of the merger - protecting both plurality and competition - would not have been the superior solution. Obviously, intensity of competition and public interest target achievement were not a tradeoff here. 
(v) Overall Evaluation:

The overall assessment of the public interest considerations included in Austrian competition policy displays room for reform. Whereas the incentives of special rules regarding mergers in the media sector are understandable, the objective could be achieved with a stricter competition policy as there is no apparent trade-off between the public interest competitive markets and the public interest media plurality. Additionally, the institution FCP is much too vague with respect to the types of public interest considerations. A clearer definition of tasks and especially relevant public interest aspects that the FCP shall preserve should be provided in order to improve transparency, legal certainty, the achievement of targets and, above all, to effectively represent non-market public interests. The arbitrariness of the public interest interpretation seems to be the most relevant problem with the current institutional settings, allocating considerable interpretation scope to and, thus, sensitively relying on the individual FCP. While the incumbent officeholder acts restrictive with respect to ostensible public interests, which are actually driven by political and vested interests, another individual in office may considerably harm the public interest in protecting competition by a loose and lobbyismfriendly "public" interest interpretation. ${ }^{5}$ Thus, a narrow definition of nonmarket public interests according to our definition (see section 1 ) is imperative.

\subsection{Public Interest Considerations in French Merger Control}

The French Minister of Economic Affairs can overrule a decision of the French Competition Authority (Autorité de la Concurrence, FCA) regarding a merger if there are reasons that are linked to industrial development, business competitiveness in terms of international competition and/or creation and preservation of employment (Autorité de la Concurrence 2018a). There are two possible starting points for the Minister to intervene in a FCA-merger case on public interest grounds: after the

As the analysis of the other merger control regimes in the following reveals, this type of abuse is far more common and more damaging than to restrict public interest to the protection of competition. 
FCAs clearing of a Phase I merger review, the Minister can ask the FCA to open a Phase II in-depth investigation. The second possibility occurs after the FCAs decision in a Phase II investigation; the Minister can then overrule this decision because of the mentioned public interest aspects. Therefore, he has the power to prohibit a pro-competitive merger or to allow an anticompetitive merger on public interest grounds (Article L. 430 - 7 - 1 Code de Commerce).

The analysis of the French merger control regime in terms of public interest considerations shows following results:

(i) Non-Market Public Interests:

The three mentioned potential public interest reasons do not trade-off with market competition and, thus, do not match our definition of non-market public interests. All of them are linked to macroeconomic effects, which can be reached better through competitive markets than through anticompetitive, market-power-creating mergers. They do not stand in conflict with the protection of competition as the general goal of merger control and competition policy. In particular the preservation of employment is highly unlikely to be achieved by combination of companies since mergers lead to the reaping of synergy effects which implies a reduction of workforce (inter alia, Seth 1990; Conyon et al. 2002; Gugler \& Yurtoglu 2004; Mukherjee et al. 2004; Margolis 2006; Chirita 2016) and an increase on involuntary unemployment (Budzinski \& Kretschmer 2016). Furthermore, mergers increase market power on labour markets, leading to worse conditions for employees (Autor et al. 2017; Naidu et al. 2018). Also, international competitiveness is actually dynamically harmed if domestic competition intensity decreases as a consequence of anticompetitive concentration. In the course of time, firms who do not have to compete on their home markets become less fit for international competition.

(ii) Transparency:

While the public interests are at least explicitly stated in the law, their formulation remains rather broad. This may lead to uncertainty for merging companies in terms of the applicability of the instrument/reasons to their specific 
case. On the other hand, this broad formulation and missing specific definition or delimitation of e.g. positive effects on the industrial development may also lead to exploitation by the companies. Such open formulations are prone to lobbyism and could be utilized by the companies to maximize their individual profits under the guise of public interests.

The specifications for the procedure are regulated in terms which increase transparency and legal certainty for all parties potentially involved. Nevertheless, the instrument was used rarely so far, thus, experience is small.

(iii) Usage:

The minister's right to re-examine a merger decision of the FCA was implemented in French merger control in 2008 with the advent of the FCA. Since that, it was used by the respective minister only once in the 2018 Agripole/Cofigeo case (Autorité de la Concurrence 2018b), where the minister used his power to clear the merger without remedies (that were imposed by the FCA, who cleared the merger under conditions) for reasons of job security (Dentons 2018).

(iv) Success/Instrumentality:

In the first case of this kind in French merger control, the remedies drawn by the FCA raised concerns in the Minister of Economic Affairs regarding the potential impact of the remedies on labour and industrial development. Therefore, he induced a "Phase III" investigation after which he overruled the FCA's decision by allowing the merger to take place without any remedies (Renner \& Kupka 2018). If, in fact, these remedies would have had a negative impact on the job situation or the industrial development of the firm and/or the French overall economy remains unclear. However, mergers in general tend to have negative effects on the number of jobs in the merged company, due to synergy effects, as well as on labour standards (see references above). Another questionable point is if the development of one single company should be put on one level with the development of the overall economy. It is at least controversial if the job situation and economic 
development of a single firm can really be of general public interest. Overall, there is no discernible conflict between the objective of preserving jobs and the objective of protecting competition. Therefore, the anticompetitive merger (now without remedies) is not likely to help achieving the goal of job preservation.

\section{(v) Overall Evaluation:}

The fact that the "evocation" power of the French Minister of Economic Affairs is not based on clearly defined public interest reasons that cannot be (better) reached through competitive markets and the rare usage of the instrument overall indicate that there is in fact no real need for it in the merger control regime - at least in the current form, which only covers economic aspects. Even after the first case of this kind in the last year, it is unclear if the instrument will be used more regularly now for instance due to the additional costs of a "Phase III" investigation.

\subsection{Public Interest Considerations in UK Merger Control}

Public interests in the current form are a part of the UK merger control since the 2002 Enterprise Act. There are several possibilities to raise specified public interest concerns to the Government: (a) the Secretary of State for Business, Energy \& Industrial Strategy can intervene in respective merger cases on grounds of national security and financial stability of the UK financial system, and (b) the Secretary of State for Digital, Culture, Media \& Sport can intervene in merger cases on grounds of media quality, plurality, and standards. It is also possible for the respective Secretary of State to intervene because of additional public interest considerations. These additional considerations can be implemented into section 58 of the 2002 Enterprise Act after the order to do so is approved by the two Houses of Parliament (as it happened in 2008, during the financial crisis, with the reason regarding financial stability). In so-called special public interest cases (c), mergers that do not meet the common thresholds for merger investigations may still be investigated solely on public interest grounds. These special ruling applies to mergers involving government contractors holding confidential information regarding the country's 
defence and certain mergers in the media sector (Chisholm \& Jung 2014; Cleary Gottlieb 2018; Mor 2018).

The proceedings of a public interest merger case are not strictly and transparently divided into a "competition-analysis part" and a "further public interests part". If the above-mentioned public interest considerations are potentially relevant for the case, the respective Secretary of State may issue a public interest considerations notice (PIIN). After this issue, the Competition and Markets Authority (CMA) examines the case in terms of competition and non-competition aspects at the same time including third party views (Phase 1). If there were in fact important public interest aspects found in Phase 1, the CMA initiates Phase 2 where additional reports are provided to the Secretary of State. The Secretary eventually is the one responsible for the decision whether or not he or she permits or allows the merger based on public interest considerations (Competition and Markets Authority 2014). The results of our analysis based on the mentioned five questions are as follows:

(i) Non-Market Public Interests:

The potential public interest aspects justifying interventions of politics are mostly not non-market and could potentially be achieved (better) through competitive markets. Only a potential threat to national security could justify an intervention of the Government on grounds of real public interests. Financial stability represents a more controversial case. In the short-run, bank mergers may be necessary to safeguard financial stability during a financial crisis, whereas, in the long-run, increased market concentration in the financial sector also increases the vulnerability of the system to future crisis (inter alia, Akins et al. 2016; Noman et al. 2017; Goetz 2018; Kim 2018).

\section{(ii) Transparency:}

The rules regarding public interest implementation in this respective merger control are transparent and the proceedings are predefined. Nevertheless, due to the unclear potential reasons and the possibility to include new public interest reasons at any time, the overall assessment of the transparency and legal certainty through the procedure is rather negative. The possibility of exploitation of the instrument by companies seems to exist. 


\section{(iii) Usage:}

The possibility of including public interest considerations into UK merger control cases was used regularly in the past. There were three cases of media mergers (the 2007 BSkyB/ITV case, the 2010 News Corporation/BSkyB case, and the 2017 Hytera/Sepura case), and one merger case that has been assessed for its potential impact on financial stability. The Lloyds-TSB/HBOS merger was also the reason to include the public interest of stability of the UK financial system in law during the 2008 financial crisis (Smith 2008). The public interest of national security was used in six cases, showing the important role of this reasoning in UK merger control. Thus, the merger rules (including the above mentioned thresholds for special public interest cases) regarding the Government's power to scrutinise mergers and takeovers that may raise national security concerns have been updated in 2018 . These new rules especially apply to tech firms developing military technology and shall keep the countries' openness to trade and investment, while not risking national security (UK Government 2018).

\section{(iv) Success/Instrumentality:}

All of the merger cases in the financial and the media sector raised controversial discussions on their actual positive effects on public interests afterwards (Graham 2013, BBC 2018). As mentioned above, the issues are either controversial or do not represent non-market public interests according to our definition. Therefore, we conclude that in fact real public interest was not protected in these cases. Without an in-depth ex-post evaluation of the other cases in the defence sector and their results, a clear statement on the actual protection of public interests in these cases is difficult to derive. Nevertheless, in these cases actual public interests, which potentially stood in conflict with the goal of protecting market competition, were taken into account and could at least potentially have overweighed the public interest of safeguarding competition. 
Overall Evaluation:

Since there is only one actual public interest aspect included in UK merger control - national security - the overall assessment of the instrument in its current form is rather negative. As in the other merger control regimes, the reasons justifying political intervention in merger cases because of potentially threatened public interests should be revised in terms of including only public interests that cannot be achieved through competition. The development of the UK merger rules concerning cases that potentially hold a threat to national security can be evaluated as positive.

\section{The Special Case of "Ministererlaubnis" in German Merger Control}

As a case study for an ex-post analysis of the actual effects of public interest considerations in merger control, we utilize the example of German merger control and the so-called ministerial approval or "Ministererlaubnis". In German merger control, competition and market analysis are meant to be strictly separated from further (e.g. public interest) aspects. The German Federal Cartel Office (Bundeskartellamt, FCO) prohibits a merger if it would significantly impede effective competition ( $\$ 36$ (1) GWB) - this decision is made solely based on competition aspects. After the FCO's decision, the companies involved can apply for a ministerial approval. This approval can be granted if, in the individual case under consideration, the competition restrictions resulting from the merger which were determined by the FCO are outweighed by (i) macroeconomic advantages, (ii) an overwhelming public interest and/or (iii) the strengthening of the international competitiveness of the companies. Prior to the decision, an opinion from the Monopolies Commission (MC) ${ }^{6}$ must be obtained, stating whether the reasons for the exception are reasonable and likely to be achieved through the anticompetitive merger. The Federal Minister of Economic Affairs decides upon the approval decision and he may deviate from the MC's advice. An approval must not be granted, however, if the anticompetitive effects of the concentration in question would jeopardize the overall market econo-

6 The MC is an independent advisory body that provides statutory (e.g., sector inquiries) and special opinions (e.g., prior to a ministerial approval) on competition policy, competition law and regulation issues and advises the government and other legislatures in these areas (Monopolkommission 2019). 
my (\$42 (1) GWB). In order to safeguard and support the public interest reasons, remedies may be combined with the permission ( $\$ 42$ (2) GWB). Overall, the decision of the Federal Minister of Economic Affairs is solely based on the three mentioned aspects and explicitly not a repeal of the decision of the FCO.

Since its implementation in the early 1970s, 23 applications for a ministerial approval were submitted to the Federal Ministry of Economic Affairs. Nine of them were granted (with or without conditions), six were rejected, seven were withdrawn by the companies during the procedure, and one is still waiting for its decision at the time of writing (Budzinski \& Stöhr 2019a). Applications were made by companies from different sectors, like energy, media, engineering, and hospitals (BMWi 2016a). Some "trends" are visible: from four applications in the energy sector, three were granted (all against the recommendation of the $\mathrm{MC}$ ); in the sector of agricultural production, all three applications were rejected (in line with the recommendations of the $\mathrm{MC}$ ); and in the automotive sector, both applications were withdrawn, presumably because of low prospects of success. An overall remarkable aspect is that the Federal Minister decided against the explicit recommendation of the $M C$ in some of the approval cases - but in none of the rejection cases. The members of the $\mathrm{MC}$ recommended a ministerial approval only four times, whereas the Federal Minister decided more than twice as many cases in favour of the companies. This may indicate how the instrument can be (ab)used to enforce particular vested/political interests.

The pros and especially the cons of this instrument have been subject to controversial academic discussion (inter alia, Lenel 1972; Gröner \& Köhler 1979; Krakowski 1989; Roth \& Voigtländer 2002; Deutscher Bundestag 2016; Bien 2016; Podszun 2016, 2017; Pomana \& Nahrmann 2016; Budzinski \& Stöhr 2019b). Stöhr \& Budzinski (2019) add to this discussion by analysing the actual effects of the nine cases where the ministerial approval was granted and by evaluating ex-post whether the goals for the approvals were actually achieved. Table 2 presents an overview on the approved cases, including the recommendation of the MC and the reasons that caused the approval (with or without conditions) by the Federal Minister. 
Table 2: Cases of Granted Ministerial Approval

\begin{tabular}{|c|c|c|}
\hline Case (Year) - Sector & $\begin{array}{c}\text { Recommendation } \\
\text { MC }\end{array}$ & Reason for approval \\
\hline $\begin{array}{l}\text { VEBA/Gelsenberg (1974) } \\
\text { - Energy }\end{array}$ & Do not approve & $\begin{array}{l}\text { Securing energy supply } \\
\text { (approved) }\end{array}$ \\
\hline $\begin{array}{l}\text { Babcock/Artos (1976) } \\
\text { - Mechanical Engineer- } \\
\text { ing }\end{array}$ & Do not approve & $\begin{array}{l}\text { Workplace security } \\
\text { (approved under conditions) }\end{array}$ \\
\hline $\begin{array}{l}\text { Thyssen/Hüller-Hille } \\
\text { (1977) } \\
\text { - Mechanical Engineer- } \\
\text { ing }\end{array}$ & $\begin{array}{l}\text { Approve under condi- } \\
\text { tions }\end{array}$ & $\begin{array}{l}\text { Workplace security for tech- } \\
\text { nically high-skilled teams } \\
\text { (securing know-how) } \\
\text { (approved under conditions) }\end{array}$ \\
\hline $\begin{array}{l}\text { VEBA/BP (1978/79) } \\
\text { - Energy }\end{array}$ & Do not approve & $\begin{array}{l}\text { Securing energy supply } \\
\text { (approved under conditions) }\end{array}$ \\
\hline $\begin{array}{l}\text { IBH/WIBAU (1981) } \\
\text { - Mechanical Engineer- } \\
\text { ing }\end{array}$ & Approve & $\begin{array}{l}\text { Workplace security } \\
\text { (approved) }\end{array}$ \\
\hline $\begin{array}{l}\text { Daimler-Benz/MBB } \\
\text { (1989) } \\
\text { - Aerospace }\end{array}$ & $\begin{array}{l}\text { Approve under condi- } \\
\text { tions }\end{array}$ & $\begin{array}{l}\text { Privatization of Airbus (risks } \\
\text { and management) and pre- } \\
\text { vention of market monopoli- } \\
\text { zation in favour of Boeing } \\
\text { (approved under conditions) }\end{array}$ \\
\hline $\begin{array}{l}\text { E.ON/Ruhrgas (2002) } \\
\text { - Energy }\end{array}$ & Do not approve & $\begin{array}{l}\text { Securing low-cost energy } \\
\text { supply } \\
\text { (approved under conditions) }\end{array}$ \\
\hline $\begin{array}{l}\text { Uniklinik Greifswald/KKH } \\
\text { Wolgast }(2007 / 08) \\
\text { - Hospital }\end{array}$ & Approve & $\begin{array}{l}\text { Securing status as University } \\
\text { Clinic and research in the } \\
\text { field of Community Medicine } \\
\text { (approved) }\end{array}$ \\
\hline $\begin{array}{l}\text { EDEKA/Kaiser's Tengel- } \\
\text { mann }(2015 / 16) \\
\text { - Food Retail }\end{array}$ & Do not approve & $\begin{array}{l}\text { Workplace security in terms } \\
\text { of quality and quantity } \\
\text { (approved under conditions) }\end{array}$ \\
\hline
\end{tabular}

Sources: BMWi 1974, 1976, 1977, 1979, 1981, 1989, 2002, 2009, $2016 \mathrm{~b}$.

Table 2 shows that the reasons leading to a ministerial approval are various and not always strictly non-market as we defined them in section 1. According to our definition of public interests, only the case of Uniklinik Greifswald/KKH Wolgast is based on aspects that cannot be achieved through competition. Other cases only 
partly include such aspects - for example, the quality of jobs in EDEKA/Kaiser's Tengelmann or the security of know-how regarding working teams in Thyssen/HüllerHille.

The overview also shows that some "groups" of reasons are more successful in terms of receiving an approval than others. Interestingly, these are mostly reasons that are formulated in a rather vague way and, thus, tend to be challenging in expost analysis. This may be due to the characteristics of public interest considerations in general or deliberately designed in order to make accountability for decisions more difficult. Nevertheless, the ex-post effects analysis shows mostly negative results, i.e. the ministerial approvals rarely achieved its own goals (only in one case completely; see table 3). This is particularly true for "public interest" considerations mixing in economic- and competition-related aspects, whereas the picture looks somewhat more positive for cases of truly non-market public interest reasoning. Table 3 gives an overview of the cases and states if the expected public interest effects of the anticompetitive merger actually occurred and if, in fact, they were accomplished through the respective merger. For that, we combine the three cases in the energy sector, where nearly the same reasoning was used in the single cases and only one particular market is relevant for the ex-post analysis.

Table 3: Effects of Ministerial-approved Mergers

\begin{tabular}{|c|c|c|c|}
\hline Case & Reason & $\begin{array}{l}\text { Effect oc- } \\
\text { curred? }\end{array}$ & $\begin{array}{l}\text { Caused by } \\
\text { merger? }\end{array}$ \\
\hline \multirow[t]{2}{*}{ Energy Cases } & Security of energy supply & Yes & No \\
\hline & $\begin{array}{l}\text { Reasonably-priced energy } \\
\text { supply }\end{array}$ & No & - \\
\hline Babcock/Artos & Workplace security & No & - \\
\hline $\begin{array}{l}\text { Thyssen/Hüller- } \\
\text { Hille }\end{array}$ & $\begin{array}{l}\text { Workplace security for tech- } \\
\text { nically high-skilled teams } \\
\text { (securing know-how) }\end{array}$ & Rather Yes & Rather Yes \\
\hline IBH/WIBAU & Workplace security & No & - \\
\hline \multirow{2}{*}{$\begin{array}{l}\text { Daimler- } \\
\text { Benz/MBB }\end{array}$} & Privatization & Rather No & - \\
\hline & $\begin{array}{l}\text { Lowering of federal subsi- } \\
\text { dies }\end{array}$ & Rather No & - \\
\hline
\end{tabular}




\begin{tabular}{|c|c|c|c|}
\hline & $\begin{array}{l}\text { Increasing competitive- } \\
\text { ness/competition }\end{array}$ & Yes & Yes \\
\hline \multirow{2}{*}{$\begin{array}{l}\text { Uniklinik } \\
\text { Greifswald/KKH } \\
\text { Wolgast }\end{array}$} & $\begin{array}{l}\text { Securing status as university } \\
\text { hospital }\end{array}$ & Yes & Yes \\
\hline & $\begin{array}{l}\text { Securing Community Medi- } \\
\text { cine research }\end{array}$ & Yes & Yes \\
\hline \multirow[t]{2}{*}{$\begin{array}{l}\text { EDEKA/Kaiser's } \\
\text { Tengelmann }\end{array}$} & $\begin{array}{l}\text { Workplace security in terms } \\
\text { of quality }(\mathrm{KT})\end{array}$ & Yes & No \\
\hline & $\begin{array}{l}\text { Workplace security in terms } \\
\text { of quantity }(K T)\end{array}$ & No & - \\
\hline
\end{tabular}

Source: translated from Stöhr \& Budzinski 2019.

Security of jobs in terms of quantity is often used as a public interest concern. However, as mentioned before, empirical evidence shows that mergers lead to overall less jobs and negative labour market effects (see references in section 2.2), whereas competition has a positive impact on the development of employment. Our analysis also shows that this is true for the respective ministerial approval cases - there are slight indications for positive effects of mergers on workplace security in only one case. In the case Edeka/Kaiser's Tengelmann, the (very specifically defined) "quality" of jobs was formally kept but only through special conditions coming with the approval. The merger itself has had negative effects on the overall job situation - jobs were already cut shortly after the ministerial approval.

The security of reasonable-priced energy supply was used as a potential positive effect of the three merger cases in the energy sector. By comparing energy price developments in different European countries and checking for potential blackouts we come to the conclusion, that there were no such blackouts and the development of energy pricing in Germany was not particularly positive in terms of price decreases or lower price increases compared to neighboring countries.

Only the hospital case can be seen as a success in terms of reaching public interest goals through an anticompetitive merger. ${ }^{7}$ In all other cases, the occurrence of the positive effects that were the reasons for the approvals cannot be verified ex-post.

This specific hospital merger was necessary to preserve the status as a university hospital, and, therefore, the education of young doctors in the region as well as the existence of the unique research area "Community Medicine". In Germany, there are specific regulations and requirements 
Our case study shows that even in such an established public interest legislation, where competition-related and non-competition aspects are strictly separated and the instrument is implemented in competition law, positive public interest effects occur only in few cases and are in even fewer cases the result of the approved anticompetitive merger. Therefore, we conclude that the instrument of a ministerial approval in its current form does not represent a beneficial part of the German competition policy - and should definitely not be extended to the European level. Our ex-post analysis shows that the instrument does not fulfil its duties - in most cases, the predicted positive public interest effects potentially coming from the merger were not capable of outweighing the negative effects on competition. Thus, the instrument must undergo significant reforms (if it is not abolished altogether). There are several possibilities for these reforms: e.g. changing the possible reasons for an approval to strictly non-market public interests, or changing the decision body (Budzinski \& Stöhr 2019b). Without such a reform, the instrument cannot be seen as a positive example for including public interest considerations into competition policy.

\section{Concluding Remarks: Economic Justification of Public Interest Considera- tions in Merger Control?}

Table 4 gives an overview of the results of our analysis (in addition to table 3 ). The overall evaluation of the differently designed instruments in all four jurisdictions tends to be rather negative - especially because of the potential public interests that may justify an intervention. These reasons are predominantly not non-market goals in a strict sense, which cannot be reached through competition but for which competition represents a potential impediment (trade-off between effective competition and public interest).

for university hospitals: in order to ensure the quality of the education of young doctors, university hospitals must minimum thresholds of case numbers of specific treatments (in particular types of surgery). Only due to the merger (increasing the number of beds and treatments), the university hospital of Greifswald could maintain meeting these thresholds in the face of a shrinking population. 
Table 4: Analysis Results for Exemplary Merger Control Regimes

\begin{tabular}{|l|l|l|l|l|}
\hline & $\begin{array}{l}\text { French Mer- } \\
\text { ger Control }\end{array}$ & $\begin{array}{l}\text { Austrian } \\
\text { Merger } \\
\text { Control }\end{array}$ & $\begin{array}{l}\text { UK Merger } \\
\text { Control }\end{array}$ & $\begin{array}{l}\text { German } \\
\text { Merger } \\
\text { Control }\end{array}$ \\
\hline $\begin{array}{l}\text { Non-Market Public In- } \\
\text { terests? }\end{array}$ & No & Partly & Partly & Partly \\
\hline $\begin{array}{l}\text { Transparency of Pro- } \\
\text { cedure }\end{array}$ & $\begin{array}{l}\text { - Proceedings } \\
\text { yes } \\
\text { - Reasons no }\end{array}$ & $\begin{array}{l}\text { - Institution } \\
\text { of Federal } \\
\text { Cartel Pros- } \\
\text { ecutor no } \\
\text { Regulation } \\
\text { of media } \\
\text { mergers yes }\end{array}$ & $\begin{array}{l}\text { - Reasons no } \\
\text { - Rea }\end{array}$ & $\begin{array}{l}\text { - Proceed- } \\
\text { ings yes }\end{array}$ \\
\hline Usage of Instrument no \\
\hline $\begin{array}{l}\text { Success/Instrumentality } \\
\text { of Instrument to reach } \\
\text { public interest goals }\end{array}$ & $\begin{array}{l}\text { Consequences } \\
\text { are not yet } \\
\text { foreseeable, } \\
\text { but rather no }\end{array}$ & Rather no & Partly & Partly \\
\hline $\begin{array}{l}\text { Overall Evaluation of } \\
\text { Instrument }\end{array}$ & $\begin{array}{l}\text { Rather nega- } \\
\text { tive }\end{array}$ & $\begin{array}{l}\text { Rather neg- } \\
\text { ative }\end{array}$ & $\begin{array}{l}\text { Rather nega- } \\
\text { tive }\end{array}$ & $\begin{array}{l}\text { Rather nega- } \\
\text { tive }\end{array}$ \\
\hline
\end{tabular}

All the current concepts suffer from descriptions or definitions of public interest that are too broad and not focused on non-market public interests, i.e. such public interests that are better achieved through market power than through effective competition and, thus, stand in a trade-off relation to the public interest of protecting competition. This offers scope for injecting vested interests of politicians, companies and other powerful lobbies into the decision process in the guise of ostensible "public" interest. At the end of the day, this harms social welfare without serving any real public interest. Consequently, the answer to our first research question, are the public interests stipulated in the respective competition laws are non-market in nature, is clearly: no, since none of the regimes limits itself to nonmarket public interests. Further deficiencies include that none of the analysed regimes and cases includes checks whether the market power resulting from the permitted anticompetitive mergers is instrumental to achieve the stated public interest goals. Given these results, it is not surprising that the empirical record of past public interest interventions into merger control is mixed at best from an ex-post 
perspective, which represents the answer to our second research question. For Germany, where we have the largest data-set of respective interventions, the desired public interest effects were (probably) achieved only in a minority of cases and in even fewer cases the market power of the allowed anticompetitive merger was instrumental in achieving the desired public interests. And there is no indication that the records for other regimes are likely to look any better. Thus, altogether, the public interest considerations in the current regimes are deficient and contribute neither to welfare nor to the interests of the public. Calls for extending provisions like these either in scope (even broader) or to the European level - like from the French-German manifesto - cannot be supported by academic analysis. It must be expected to be detrimental to social welfare without serving any real public interest. Only vested interests and the forces of lobbyism are likely to benefit from such a reform.

Quite in contrast to the calls for an extension, a beneficial reform must narrow and focus the scope for public interest considerations and provide institutional checks and balances against abuses. First and foremost, only non-market public interest can provide a ground for overriding competition-focused merger control decisions. In order to safeguard this, we propose a four-step test (Budzinski \& Stöhr 2019b):

a. Identification of a social goal that is demonstrably in the interest of the general public.

b. Evidence of a trade-off between this public goal and effective competition.

c. Proof that this goal is better achieved by market power than by the protection of the competition process.

d. Balancing the welfare costs of the considerable weakening of effective competition with the benefits of better fulfilment of the social goal, including proof that no alternative, "milder" instruments exist that would enable an equivalent achievement of the social goal.

The enforcement of this test must be given in the hands of an independent decision-making body like a law court. In order to maintain transparency and in order to protect the competition authority from political pressure, it should be strictly separated from the competition policy analysis and decision. If a competent au- 
thority (for instance, a government unit or a specialised authority) wants to get a merger control decision overruled on public interest grounds, it needs to seek permission of an anticompetitive merger or prohibition of a procompetitive merger in front of the court. The burden of proof with respect to all four steps must be allocated to the party seeking the overturning of the merger control decision on public interests grounds (Budzinski \& Stöhr 2019b).

In the aftermath of the prohibited Siemens/Alstom merger, the latest controversy around public interest considerations in EU merger control focuses on promoting National or European Champions. German and French politicians are calling for "a more ambitious European industrial strategy with clear objectives for 2030" (BMWi 2019: 1) including, besides other things, changes in European merger guidelines and better possibilities to subsidize European companies to promote their international competitiveness (BMWi 2019: 4). This implies that there would be a public interest for generating and/or supporting European Champions and that this represents a trade-off with effective domestic competition. The underlying logic would be that companies with domestic market power can use the supracompetitive rents from domestic markets (which are yielded on the expense of customers and society) to increase their international competitiveness and, thus, reap higher rents from foreign markets that overcompensate the domestic welfare losses. However, there is vast theoretical and empirical evidence that companies protected from domestic competition tend to concentrate on exploiting their market power to the detriment of consumers and society as well as on lobbying for and extending non-competitive pensions and privileges (rent-seeking instead of competitiveness) - ultimately also to the detriment of their international competitiveness (inter alia, Jenny \& Neven 2019, Motta et al. 2019, Zettelmeyer 2019). Thus, there is no non-market public interest in protecting single industries or companies from (national or international) competition. An introduction of such "fake" public interest considerations into European competition law would be the wrong way for the new Commission to start into their legislation period. 


\section{References}

Akins, B.; Li, L.; Ng, J. \& Rusticus, T. O. (2016), Bank Competition and Financial Stability: Evidence from the Financial Crisis. Journal of Financial and Quantitative Analysis, Vol. 51(1), pp. 1-28.

Anderson, S. P. \& McLaren, J. (2012), Media Mergers and Bias with Rational Consumers. Journal of the European Economic Association, Vol. 10(4), pp. 831-859.

Autor, D., Dorn, D., Katz, L. F., Patterson, C. \& Van Reenen, J. (2017), Concentrating on the Fall of the Labor Share. American Economic Review, Vol. 107(5), pp. 180185.

Autorité de la Concurrence (2018a), Q\&A on the Cofigeo case, URL: http://www.autoritedelaconcurrence.fr/doc/questions_reponses_final.pdf (accessed April 16, 2019).

Autorité de la Concurrence (2018b), Press Release 14 June 2018: Acquisition of William Saurin - reaction of the Autorité after the Minister of Economy's decision, URL:

http://www.autoritedelaconcurrence.fr/user/standard.php?id_rub=684\&id_articl $\mathrm{e}=3192$ \&lang $=$ en (accessed April 16, 2019).

Barbier de la Serre, E. (2006), Accelerated and Expedited Procedures before the EC Court: A Review. Common Market Law Review, Vol. 43(3), pp. 783-815.

BBC (2018), What are the issues in Fox's Sky deal?, URL:

https://www.bbc.com/news/business-40434381 (accessed May 16, 2019).

Beirat für Wirtschafts- und Sozialfragen (2010), Zukunft der Wettbewerbspolitik in Österreich, Nr. 84.

Bien, F. (2016), Die Berücksichtigung nichtwettbewerblicher Aspekte in der Fusionskontrolle - Gibt es Alternativen zur Ministererlaubnis? NZKart, Vol. 4(10), pp. 445-446.

BMWi (1974), „VEBA/Gelsenberg”, Erlaubnis eines Zusammenschlusses zur Sicherung der Energieversorgung, Verfügung des Bundeswirtschaftsministers vom 1. Februar 1974. WuW, Vol. 24, pp. 343-344. 
BMWi (1976), „Babcock/Artos“, Erlaubnis eines Zusammenschlusses unter Auflagen, Verfügung des Bundeswirtschaftsministers vom 17. Oktober 1976. WuW, Vol. 26, pp. 659-663.

BMWi (1977), „Thyssen/Hüller-Hille”, Teilerlaubnis eines Zusammenschlusses mit Entflechtungsauflage, Verfügung des Bundeswirtschaftsministers vom 1. August 1977. WuW, Vol. 27, pp. 663-668.

BMWi (1979), „VEBA/BP”, Erlaubnis eines Zusammenschlusses zur Absicherung der Energieversorgung, Verfügung des Bundeswirtschaftsministers vom 5. März 1979. WuW, Vol. 29, pp. 499-508.

BMWi (1981), „IBH/WIBAU“, Ministererlaubnis wegen Verbesserung der Möglichkeiten des Marktzutritts auf Auslandsmärkten und Erhaltung von Arbeitsplätzen, Verfügung des Bundeswirtschaftsministers vom 9. Dezember 1981. WuW, Vol. 31, pp. 163-168.

BMWi (1989), „Daimler-Benz/MBB“, Ministererlaubnis eines Zusammenschlusses mit erheblichen Auswirkungen auf Märkte für Rüstungsgüter, Verfügung des Bundeswirtschaftsministers vom 6. September 1989. WuW, Vol. 39, pp. 947-962. BMWi (2002), "E.ON/Ruhrgas", Ministererlaubnis unter Auflagen, Verfügung des Bundeswirtschaftsministers vom 5. August 2002. WuW, Vol. 52, pp. 751-776. BMWi (2009), „Uniklinikum Greifswald/KKH Wolgast”, Wissenschaftliche Bedeutung als Gemeinwohlgrund, Verfügung des Bundeswirtschaftsministers vom 17. April 2008. WuW, Vol. 59, pp. 683-696.

BMWi (2016a), Übersicht über die bisherigen Anträge auf Ministererlaubnis nach § 24 Abs. 3/§42 GWB.

BMWi (2016b), Verfügung in dem Verwaltungsverfahren Edeka/Kaiser's Tengelmann, Gesch.-Z.: I B 2 - 2208 50/01.

BMWi (2019), Franco-German Manifesto for a European industrial policy fit for the $21^{\text {st }}$ Century, URL: https://www.bmwi.de/Redaktion/DE/Downloads/F/francogerman-manifesto-for-a-european-industrialpolicy.pdf?_blob=publicationFile\&v=2 (accessed April 3, 2019).

Budzinski, O. (2006), An Economic Perspective on the Jurisdictional Reform of the European Merger Control System. European Competition Journal, Vol. 2(1), pp. 119-140. 
Budzinski, O. (2010), An Institutional Analysis of the Enforcement Problems in Merger Control. European Competition Journal, Vol. 6(2), pp. 445-474.

Budzinski, O. (2018), The Governance of Global Competition: Competence Allocation in International Competition Policy, Cheltenham: Elgar.

Budzinski, O. \& Christiansen, A. (2005), Competence Allocation in EU Competition Policy as an Interest-Driven Process. Journal of Public Policy, Vol. 25(3), pp. 313337.

Budzinski, O. \& Kretschmer, J. P. (2016), Horizontal Mergers, Involuntary Unemployment, and Welfare. Journal of Economic Research, Vol. 21(3), pp. 297-317.

Budzinski, O. \& Stöhr, A. (2019a), Ministererlaubnis für die Fusion Miba/Zollern: Europäische Champions statt Wettbewerb? Wirtschaftsdienst, Vol. 99(7), pp. 505-510.

Budzinski, O. \& Stöhr, A. (2019b), Die Ministererlaubnis als Element der deutschen Wettbewerbsordnung: eine theoretische und empirische Analyse. ORDO, Vol. 69, in print.

Bundeskanzleramt (2019), Medienfusionskontrolle, URL: https://www.bundeskanzleramt.gv.at/-/medienfusionskontrolle (accessed April 17, 2019).

Bundesministerium Verfassung, Reformen, Deregulierung und Justiz (2019), Der Bundeskartellanwalt, URL:

https://www.justiz.gv.at/web2013/home/justiz/justizbehoerden/derbundeskartellanwalt 8ab4a8a422985de30122a92c3e89637f.de.html (accessed May 28, 2019).

Chirita, A. D. (2016), The Impact of Economic Efficiency on Employment: A Case Study of Mergers \& Acquisitions, Discussion Paper, Durham University 2016. Chisholm, A. \& Jung, N. (2014), The Public Interest and Competition-Based Scrutiny of Mergers: Lessons from the Evolution of Merger Control in the United Kingdom. CPI Antitrust Chronicle, October 2014 (1).

Cleary Gottlieb (2018), Alert Memorandum - UK Introduces New Thresholds for National Security Mergers, https://www.clearygottlieb.com/-/media/files/alertmemos-2018/uk-introduces-new-thresholds-for-national-security-mergerspdf.pdf (accessed May 13, 2019). 
Coase, R. H. (1974), The Market for Goods and the Market for Ideas. American Economic Review, Vol. 64(2), pp. 384-391

Competition and Markets Authority (2014), Mergers: Guidance on the CMA's jurisdiction and procedure.

Conyon, M. J.; Girma, S.; Thompson, S. \&Wright, P.W. (2002), The Impact of Mergers and Acquisitions on Company Employment in the United Kingdom. European Economic Review, Vol. 46(1), pp. 31-49.

Dentons (2018), Competition Newsletter August 2018, URL: https://www.dentons.com/en/pdf-pages/generatelistingpagepdf?isPdf= true\&Itemld =ubZ35SKD3ZNdhvCRXetaOe/ oA8iULfZgg65fQXJVce7pTClbiwHOIw= = (accessed April 16, 2019)

Deutscher Bundestag (2016), Antrag auf Parlaments- statt Ministererlaubnis, Drucksache 18/10240, Berlin.

European Commission (2019), Press Release - Mergers: Commission prohibits Siemen's proposed acquisition of Alstom, URL: https://europa.eu/rapid/pressrelease_IP-19-881_en.htm (accessed August 13, 2019).

Gentzkow, M. \& Shapiro, J. (2006), Media Bias and Reputation. Journal of Political Economy, Vol. 114(2), pp. 280-316.

Gentzkow, M. \& Shapiro, J. (2008), Competition and Truth in the Market for News. Journal of Economic Perspectives, Vol. 22(2), pp. 133-154

Goetz, M. R. (2018), Competition and bank stability. Journal of Financial Intermediation, Vol. 35(A), pp. 57-69.

Graham, C. (2013), Public Interest Mergers. European Competition Journal, Vol. 9(2), pp. 383-406.

Gröner, H. \& Köhler, H. (1979), Wettbewerbsprobleme der Sanierungsfusion. ORDO, Vol. 30, pp. 87-126.

Gugler, K. \& Yurtoglu, B. B. (2004). The Effects of Mergers on Company Employment in the USA and Europe. International Journal of Industrial Organization, Vol. 22(4), pp. 481-502.

Jenny, F. \& Neven, D. (2019), Competition policy in the aftermath of the Siemens/Alstom prohibition: An agenda for the new Commission. Concurrences, $\mathrm{N}^{\circ}$ 2-2019, pp. 2-5. 
Kim, J. (2018), Bank Competition and Financial Stability: Liquidity Risk Perspective. Contemporary Economic Policy, Vol. 36(2), pp. 337-362.

Krakowski, M. (1989), Gemeinwohlvorteile durch Großfusion? Wirtschaftsdienst, Vol. 69(8), p. 368.

Lenel, H. O. (1972), Zum Teerfarbenurteil und zur sogenannten Fusionskontrolle. ORDO, Vol. 23, pp. 307-328.

Mair, A. \& Stifter, G. (2015), Republik Österreich: Bundeskartellanwalt - Tätigkeitsbericht 2015.

Mair, A. \& Stifter, G. (2016), Republik Österreich: Bundeskartellanwalt - Tätigkeitsbericht 2016.

Mair, A., Stifter, G. \& Majer, H. L. (2017), Republik Österreich: Bundeskartellanwalt - Tätigkeitsbericht 2017.

Margolis, D. N. (2006), Should Employment Authorities Worry About Mergers and Acquisitions. Portuguese Economic Journal, Vol. 5(2), pp. 167-194.

Monopolkommission (2019), Mission, URL:

http://www.monopolkommission.de/en/monopolies-commission/mission.html (accessed March 26, 2019).

Mor, F. (2018), Contested mergers and takeovers, House of Commons Library, Briefing Paper No. 5374.

Motta, M. et al. (2019), Open letter on European Champions: More, not less, competition is needed in Europe, URL:

https://www.competitionpolicyinternational.com/wp-content/uploads/

2019/02/Open-letter-on-European-champions-with-signatures.pdf (accessed August 13, 2019).

Mukherjee, T. K., Kiymaz, H. \& Baker, H. K. (2004), Merger Motives and Target Valuation: A Survey of Evidence from CFO's. Journal of Applied Finance, Vol. 14(2), pp. 7-24.

Mullainathan, S. \& Shleifer, A. (2005), The Market for News. American Economic Review, Vol. 95(4), pp. 1031-1053

Naidu, S., Posner, E. \& Weyl, E. G. (2018), Antitrust Remedies for Labor Market Power. Harvard Law Review, Vol. 132(2), pp. 537-601. 
Noman, A. H. Md; Gee, C. S. \& Isa, C. R. (2017), Does competition improve financial stability of the banking sector in ASEAN countries? An empirical analysis. PLoS ONE, Vol. 12(5): e0176546.

OECD (2016a), Public Interest Considerations in Merger Control - Background Paper by the Secretariat, DAF/COMP/NP3(2016)3.

OECD (2016b), Public Interest Considerations in Merger Control - Summaries of contributions, DAF/COMP/WP3/WD(2016)30.

Pappas, S. A. \& Demortain, D. (2004), A New Era of Competition under the Guidance of the Court of First Instance. In: J. Eekhoff (ed.), Competition Policy in Europe, Berlin: Springer, pp. 233-245.

Podszun, R. (2016), Die Ministererlaubnis - Einbruch der Politik ins Recht der Wirtschaft. Neue Juristische Wochenschrift, Vol. 9, pp. 617-619.

Podszun, R. (2017), Die 9. Novelle des Gesetzes gegen Wettbewerbsbeschränkungen (GWB) - Stellungnahme als Sachverständiger im Wirtschaftsausschuss des Deutschen Bundestages zur Vorbereitung der Anhörung am 23.1.2017, Düsseldorf.

Pomana, A. \& Nahrmann, J. (2016), Ministererlaubnis für den Erhalt von Arbeitsplätzen? Betriebs Berater, Vol. 20, pp. 1155-1162.

Renner, C. \& Kupka, P. (2018), Developments in National Competition Laws (April 1, 2018 - June 30, 2018) - France. Wirtschaft und Wettbewerb, Vol. 68(9), p. 459.

Roth, S. J. \& Voigtländer, M. (2002), Die Ministererlaubnis für den Zusammenschluss von Unternehmen - ein Konflikt mit der Wettbewerbsordnung. Zeitschrift für Wirtschaftspolitik, Vol. 51(2), pp. 231-251.

Seth, A. (1990), Sources of Value Creation in Acquisitions: An Empirical Investigation. Strategic Management Journal, Vol. 11(6), pp. 431-446.

Smith, L. (2008), The Lloyds-TSB and HBOS Merger: Competition Issues, House of Commons Library, SN/BT/4907.

Stöhr, A. \& Budzinski, O. (2019), Ex-post Analyse der Ministererlaubnis-Fälle - Gemeinwohl durch Wettbewerbsbeschränkungen?, Ilmenau Economics Discussion Papers, Vol. 25(124). 
UK Government (2018), Press release: New merger and takeover rules come into force, URL: https://www.gov.uk/government/news/new-merger-and-takeoverrules-come-into-force (accessed May 16, 2019).

Zettelmeyer, J. (2019), The Return of Economic Nationalism in Germany, PIIE Policy Brief 19-4. 


\title{
Diskussionspapiere aus dem Institut für Volkswirtschaftslehre
}

\author{
der Technischen Universität IImenau
}

Nr. 69 Budzinski, Oliver: Empirische Ex-Post Evaluation von wettbewerbspolitischen Entscheidungen: Methodische Anmerkungen, Januar 2012.

Nr. 70 Budzinski, Oliver: The Institutional Framework for Doing Sports Business: Principles of EU Competition Policy in Sports Markets, January 2012.

Nr. 71 Budzinski, Oliver; Monostori, Katalin: Intellectual Property Rights and the WTO, April 2012.

Nr. 72 Budzinski, Oliver: International Antitrust Institutions, Juli 2012.

Nr. 73 Lindstädt, Nadine; Budzinski, Oliver: Newspaper vs. Online Advertising Is There a Niche for Newspapers in Modern Advertising Markets?

Nr. 74 Budzinski, Oliver; Lindstädt, Nadine: Newspaper and Internet Display Advertising - Co-Existence or Substitution?, Juli 2012b.

Nr. 75 Budzinski, Oliver: Impact Evaluation of Merger Control Decisions, August 2012.

Nr. 76 Budzinski, Oliver; Kuchinke, Björn A.: Deal or No Deal? Consensual Arrangements as an Instrument of European Competition Policy, August 2012.

Nr. 77 Pawlowski, Tim, Budzinski, Oliver: The (Monetary) Value of Competitive Balance for Sport Consumers, Oktober 2012.

Nr. 78 Budzinski, Oliver: Würde eine unabhängige europäische Wettbewerbsbehörde eine bessere Wettbewerbspolitik machen?, November 2012.

Nr. 79 Budzinski, Oliver; Monostori, Katalin; Pannicke, Julia: Der Schutz geistiger Eigentumsrechte in der Welthandelsorganisation - Urheberrechte im TRIPS Abkommen und die digitale Herausforderung, November 2012.

Nr. 80 Beigi, Maryam H. A.; Budzinski, Oliver: On the Use of Event Studies to Evaluate Economic Policy Decisions: A Note of Caution, Dezember 2012.

Nr. 81 Budzinski, Oliver; Beigi, Maryam H. A.: Competition Policy Agendas for Industrializing Countries, Mai 2013.

Nr. 82 Budzinski, Oliver; Müller, Anika: Finanzregulierung und internationale Wettbewerbsfähigkeit: der Fall Deutsche Bundesliga, Mai 2013. 
Nr. 83 Doose, Anna Maria: Methods for Calculating Cartel Damages: A Survey, Dezember 2013.

Nr. 84 Pawlowski, Tim; Budzinski, Oliver: Competitive Balance and Attention Level Effects: Theore-tical Considerations and Preliminary Evidence, März 2014.

Nr. 85 Budzinski, Oliver: The Competition Economics of Financial Fair Play, März 2014.

Nr. 86 Budzinski, Oliver; Szymanski, Stefan: Are Restrictions of Competition by Sports Associations Horizontal or Vertical in Nature?, März, 2014.

Nr. 87 Budzinski, Oliver: Lead Jurisdiction Concepts Towards Rationalizing Multiple Competition Policy Enforcement Procedures, Juni 2014.

Nr. 88 Budzinski, Oliver: Bemerkungen zur ökonomischen Analyse von Sicherheit, August 2014.

Nr. 89 Budzinski, Oliver; Pawlowski, Tim: The Behavioural Economics of Competitive Balance: Implications for League Policy and Championship Management, September 2014.

Nr. 90 Grebel, Thomas; Stuetzer, Michael: Assessment of the Environmental Performance of European Countries over Time: Addressing the Role of Carbon, September 2014.

Nr. 91 Emam, Sherief; Grebel, Thomas: Rising Energy Prices and Advances in Renewable Energy Technologies, July 2014.

Nr. 92 Budzinski, Oliver; Pannicke, Julia: Culturally-Biased Voting in the Eurovision Song Contest: Do National Contests Differ?, December 2014.

Nr. 93 Budzinski, Oliver; Eckert, Sandra: Wettbewerb und Regulierung, März 2015.

Nr. 94 Budzinski, Oliver; Feddersen, Arne: Grundlagen der Sportnachfrage: Theorie und Empirie der Einflussfaktoren auf die Zuschauernachfrage, Mai 2015.

Nr. 95 Pannicke, Julia: Abstimmungsverhalten im Bundesvision Song Contest: Regionale Nähe versus Qualität der Musik, Oktober 2015.

Nr. 96 Budzinski, Oliver; Kretschmer, Jürgen-Peter: Unprofitable Horizontal Mergers, External Effects, and Welfare, October 2015.

Nr. 97 Budzinski, Oliver; Köhler, Karoline Henrike: Is Amazon The Next Google?, October 2015. 
Nr. 98 Kaimann, Daniel; Pannicke, Julia: Movie success in a genre specific contest: Evidence from the US film industry, December 2015.

Nr. 99 Pannicke, Julia: Media Bias in Women's Magazines: Do Advertisements Influence Editorial Content?, December 2015.

Nr. 100 Neute, Nadine; Budzinski, Oliver: Ökonomische Anmerkungen zur aktuellen Netzneutralitätspolitik in den USA, Mai 2016.

Nr. 101 Budzinski, Oliver; Pannicke, Julia: Do Preferences for Pop Music Converge across Countries? - Empirical Evidence from the Eurovision Song Contest, Juni 2016.

Nr. 102 Budzinski, Oliver; Müller-Kock, Anika: Market Power and Media Revenue Allocation in Professonal Sports: The Case of Formula One, Juni 2016.

Nr. 103 Budzinski, Oliver: Aktuelle Herausforderungen der Wettbewerbspolitik durch Marktplätze im Internet, September 2016.

Nr. 104 Budzinski, Oliver: Sind Wettbewerbe im Profisport Rattenrennen?, Februar 2017.

Nr. 105 Budzinski, Oliver; Schneider, Sonja: Smart Fitness: Ökonomische Effekte einer Digitalisierung der Selbstvermessung, März 2017.

Nr. 106 Budzinski, Oliver; Pannicke, Julia: Does Popularity Matter in a TV Song Competition? Evidence from a National Music Contest, April 2017.

Nr. 107 Budzinski, Oliver; Grusevaja, Marina: Die Medienökonomik personalisierter Daten und der Facebook-Fall, April 2017.

Nr. 108 Budzinski, Oliver: Wettbewerbsregeln für das Digitale Zeialter - Die Ökonomik personalisierter Daten, Verbraucherschutz und die 9.GWB-Novelle, August 2017.

Nr. 109 Budzinski, Oliver: Four Cases in Sports Competition Policy: Baseball, Judo, Football, and Motor Racing, September 2017.

Nr. 110 Budzinski, Oliver: Market-internal Financial Regulation in Sports as an Anticompetitive Institution, October 2017.

Nr. 111 Bougette, Patrice; Budzinski, Oliver; Marty, Frédéric: EXPLOITATIVE ABUSE AND ABUSE OF ECONOMIC DEPENDENCE: WHAT CAN WE LEARN FROM THE INDUSTRIAL ORGANIZATION APPROACH?, December 2017.

Nr. 112 Budzinski, Oliver; Gaenssle, Sophia: The Economics of Social Media Stars: An Empirical Investigation of Stardom, Popularity, and Success on YouTube, Januar 2018. 
Nr. 113 Gaenssle, Sophia; Budzinski, Oliver; Astakhova Daria: Conquering the Box Office: Factors, influencing Success of International Movies in Russia, Mai 2018.

Nr. 114 Budzinski, Oliver; Stöhr, Annika: Die Ministererlaubnis als Element der deutschen Wettbewerbsordnung: eine theoretische und empirische Analyse, Juli 2018.

Nr. 115 Budzinski, Oliver; Kuchinke, Björn A.: Modern Industrial Organization Theory of Media Markets and Competition Policy Implications, September 2018.

Nr. 116 Budzinski, Oliver; Lindstädt-Dreusicke, Nadine: The New Media Economics of Video-on-Demand Markets: Lessons for Competition Policy, Oktober 2018.

Nr. 117 Budzinski, Oliver; Stöhr, Annika: Competition Policy Reform in Europe and Germany - Institutional Change in the Light of Digitization, November 2018.

Nr. 118 Budzinski, Oliver; Noskova, Victoriia; Zhang, Xijie: The Brave New World of Digital Personal Assistants: Benefits and Challenges from an Economic Perspective, December 2018.

Nr. 119 Bougette, Patrice; Budzinski, Oliver \& Marty, Frédéric: EXPLOITATIVE ABUSE AND ABUSE OF ECONOMIC DEPENDENCE: WHAT CAN WE LEARN FROM AN INDUSTRIAL ORGANIZATION APPROACH? [Updated Version 2018], December 2018.

Nr. 120 Bartelt, Nadja: Bundling in Internetmärkten - Ökonomische Besonderheiten, Wettbewerbseffekte und Regulierungsimplikationen, Dezember 2018.

Nr. 121 Budzinski, Oliver; Feddersen, Arne: Measuring Competitive Balance in Formula One Racing, März 2019.

Nr. 122 Budzinski, Oliver; Kohlschreiber, Marie; Kuchinke, Björn A. \& Pannicke, Julia: Does Music Quality Matter for Audience Voters in a Music Contest, März 2019.

Nr. 123 Gaenssle, Sophia; Budzinski, Oliver: Stars in Social Media: New Light Through Old Windows?, April 2019.

Nr. 124 Stöhr, Annika; Budzinski, Oliver: Ex-post Analyse der MinistererlaubnisFälle - Geminwohl durch Wettbewerbsbeschränkungen?, April 2019. 
Nr. 125 Budzinski, Oliver; Lindstädt-Dreusicke, Nadine: The New Media Economics of Video-on-Demand Markets: Lessons for Competition Policy (Updated Version), May 2019.

Nr. 126 Stöhr, Annika; Noskova, Victoriia; Kunz-Kaltenhäuser, Philipp; Gaenssle, Sophia \& Budzinski, Oliver: Happily Ever After? - Vertical and Horizontal Mergers in the U.S. Media Industry, June 2019.

Nr. 127 Budzinski, Oliver; Stöhr, Annika: Der Ministererlaubnis-Fall Miba/Zollern: Europäische Champions statt Wettbewerb?, Juni 2019.

Nr. 128 Budzinski, Oliver; Gaenssle, Sophia \& Kunz-Kaltenhäuser, Philipp: How Does Online Streaming Affect Antitrust Remedies to Centralized Marketing? The Case of European Football Broadcasting, Rights, July 2019.

Nr. 129 Budzinski, Oliver; Haucap, Justus: Kartellrecht und Ökonomik: Institutions Matter!, July 2019. 